\title{
Allelopathic Chemical Screening of Aqueous Extracts of Coir Pith on Seedling Growth of Black Gram (Vigna mungo L.) and Green Gram (Vigna radiata L.)
}

Anbarasu Mariyappillai', Gurusamy Arumugam², Swaminathan Chitraputhira Pillai ${ }^{3}$, Durai Singh Ramaiah ${ }^{3}$

10.18805/LR-4703

\begin{abstract}
Background: Black gram (Vigna mungo L.) and green gram (Vigna radiata L.) were mostly used as chemical residue indicators for testing the persistence of pesticides, fungicides and herbicides, etc. in the soil. Presently, the coir pith was used as a medium of nursery for many seeds and seedling production. This study evaluated the inhibition effects and screening of allelopathic chemicals from aqueous extracts of coir pith and composting coir pith on the black gram and green gram by response index method and GCMS/ MS analysis.

Methods: The coir pith and composted coir pith soaked the ratio of 1:10 for 24 hrs, filtered through Whatman No.1 filter paper. The inhibition effect tested for germination and seedling growth of black gram and green gram was sown in poly pots. The carbon: nitrogen ratio and the total organic carbon were analyzed by dry combustion method, Kjeldahl method and GCMS/MS analysis.

Result: The phytotoxic substances are present in coir pith, which can be exterminated by composting the coir pith for better growth and development of seedlings. The negative response index (RI), high C: $\mathrm{N}$ ratio and chemical compounds like tocopherol, fucoxanthin, tetramethyl heptadeca, dichloroacetamide, tetrazole, hydroxyethyl palmitate, neocurdione and uridine derivations present in raw coir may have the phytotoxic effect and produced yellowing symptoms in young plants compared to composted coir pith. This is exterminated by composting the coir pith for better growth and development of seedlings as well as used for various agricultural and horticultural nurseries.

Key words: Allelopathic chemical, C: N ratio, Coir pith, Composted coir pith, Inhibition effect, Response index.
\end{abstract}

\section{INTRODUCTION}

Coir is a $100 \%$ natural happening fiber got from an inexhaustible asset of coconut husk. Coir strands take after the wood filaments regarding actual properties and compound organization. Coconut strands are seen firmly stuffed alongside non-sinewy, cushioned and lightweight corky material known as coir substance or coir dust, which comprises around 50-70 per cent of the husk. The elastic material that ties the coir fiber in the husk is the coir pith. Coir pith is currently utilized as a medium for seedling nurseries, for bedding plants, for preparing blend supplies for aqua-farming, production of blossoms, vegetables, trees, bushes, manure receptacles, vertical farming and packaging layer for mushrooms. As of now, coir pith stands apart as the eco-accommodating and more dependable swap for the sphagnum peat greenery, rock fleece and sawdust. Coir pithbased items give a superb developing and pulling mechanism for hydroponics or container-based plant development. Wide variations in the $\mathrm{C}$ : $\mathrm{N}$ ratio of coir pith from 58:1 to $112: 1$ has been accounted for by the different scientists. Coir pith obtained from fully mature nuts has higher amounts of lignin and cellulose and a lesser amount of water-soluble salts compared to younger nuts. The coir pith is used as a medium of mat nursery for the germination of paddy seeds and seedling production. Using coir pith affected seed germination and seedling growth and had the least values for germination, growth and physiological
${ }^{1}$ Department of Agronomy, JSA College of Agricultural and Technology, Tamil Nadu Agricultural University, Cuddalore-606 108, Tamil Nadu, India.

${ }^{2}$ Dry land Agricultural Research Station, Tamil Nadu Agricultural University, Chettinad-630 102, Sivagangai, Tamil Nadu, India.

${ }^{3}$ Department of Agronomy, Agricultural College and Research Institute, Tamil Nadu Agricultural University, Madurai-625 104, Tamil Nadu, India.

Corresponding Author: Anbarasu Mariyappillai, Department of Agronomy, JSA College of Agricultural and Technology, Tamil Nadu Agricultural University, Cuddalore-606 108, Tamil Nadu, India. Email: manbarasu102@gmail.com

How to cite this article: Mariyappillai, A., Arumugam, G., Pillai, S.C. and Ramaiah, D.S. (2022). Allelopathic Chemical Screening of Aqueous Extracts of Coir Pith on Seedling Growth of Black Gram (Vigna mungo L.) and Green Gram (Vigna radiata L.). Legume Research. DOI: 10.18805/LR-4703.

Submitted: 21-06-2021 Accepted: 08-12-2021 Online: 05-01-2022

parameters in nursery plants by mat nursery. The application of raw coir pith in nursery preparation may inhibit plant growth due to the wide $\mathrm{C}$ : $\mathrm{N}$ ratio, polyphenols and phenolic acids that made plants develop toxic yellowing phytotoxic symptoms. With this proof, the coir pith extracts were prepared and tested for their inhibitory effect and screening of allopathic chemicals based on germination, shoot and 
root length $(\mathrm{cm})$ as well as fresh and dry weight of Black gram and Green gram by Response Index method.

\section{MATERIALS AND METHODS}

The inhibition effects of aqueous extract of coir pith have experimented during January 2021 at the Department of Agronomy, Agricultural College and Research Institute, Tamil Nadu Agricultural University, Madurai, Tamil Nadu, India located at $9^{\circ} 54^{\prime} \mathrm{N}$ latitude and $78^{\circ} 54^{\prime} \mathrm{E}$ longitude.

The coir pith and composted coir pith were soaked separately in distilled water at a weight/volume ratio of $1: 10$ for $24 \mathrm{hrs}$. This ratio produces low osmolality. After 24 hours, the aqueous extracts were filtered through Whatman No.1 filter paper. The aqueous extracts were filtered and tested for inhibition of germination and seedling growth of black gram [Vigna mungo (L.)] and green gram [Vigna radiata (L.)]. Twenty-five seeds were sown in poly pots of $25 \times 25 \mathrm{~cm}$ size, filled with coir pith (Anbarasu and Swaminathan, 2021). The poly pots were added with the aqueous extracts frequently to avoid drying up. Distilled water was served as control. The germination (\%), shoot length $(\mathrm{cm})$, root length $(\mathrm{cm})$, fresh weight $(\mathrm{mg})$ and dry weight $(\mathrm{mg})$ of black gram and green gram were recorded after two weeks. The magnitude of inhibition versus simulation in the bioassay was compared through the response index (RI) (Richardson and Williamson, 1988) is determined as follows,

$$
\begin{aligned}
& \text { if } T>C, R I=1-(C / T) \\
& \text { if } T=C \text {, then } R I=0 \\
& \text { if } T<C \text {, then } R I=(T / C)-1
\end{aligned}
$$

Where,

$\mathrm{T}$ is the treatment mean and $\mathrm{C}$ is the control mean. A negative $\mathrm{RI}$ reflects the proportional disparity in output (germination $(\%)$, shoot length $(\mathrm{cm})$, root length $(\mathrm{cm})$, fresh weight $(\mathrm{mg})$ and dry weight $(\mathrm{mg})$ ) of test crop in the treatment relative to output in the control. The results were subjected to an analysis of variance (Ayeni et al., 1997) and mean RI values were tested for standard error.

The total organic carbon content in coir pith was analyzed through dry combustion method at $540^{\circ} \mathrm{C}$ for $4 \mathrm{hr}$ and total nitrogen content by the Kjeldahl method (Bremmer and Mulvaney, 1982).

For analyzing the chemical compounds present in the coir pith, GCMS/MS analysis was done. A volume of 1 micro lit of clear extract was injected into GCMS/MS with an oven programming of $80^{\circ} \mathrm{C} @ 5^{\circ} \mathrm{C} / \mathrm{min}$ to $250^{\circ} \mathrm{C}(10 \mathrm{~min})$. The injector temperature was maintained at $220^{\circ} \mathrm{C}$ with the detector temperature of $250^{\circ} \mathrm{C}$. The carrier gas used in the analysis was helium which had a flow rate of $1 \mathrm{ml} / \mathrm{min}$. A 30 $m$ length of capillary column HP5 Polar type was used. The GCMS/MS analysis was done at the Department of Agricultural Entomology, Agricultural College and Research Institute, Tamil Nadu Agricultural University, Madurai.

For identification of the components, interpretation on mass spectrum GCMS/MS was conducted using the database of national institute standard and technology
(NIST) having more than 62,000 patterns. The spectrum of the unknown component was compared with the spectrum of the known components stored in the NIST library. The name, molecular weight and structure of the component of the test materials were ascertained.

The Coir pith was composted by inoculating with a proprietary bio-formulation, such as PITH PLUS (Pleurotus sajor caju) and enriched with urea show a definite reduction in lignin and cellulose contents with an increase in total nitrogen and other nutrient elements after 30 days.

\section{Statistical analysis}

The results for each characterization data were obtained from the mean procedure of three replicates and statistical analysis was performed in a complete randomization design. The data on various parameters studied during the investigation were statistically analyzed by applying the technique of standard error deviation $( \pm)$, as suggested by Gomez and Gomez, (1984).

\section{RESULTS AND DISCUSSION}

Carbon to Nitrogen ratio $(\mathrm{C}: \mathrm{N})$ is a ratio of the mass of carbon to a mass of nitrogen in a substance. For example, a C: $N$ of 10:1 means there are ten units of carbon for each unit of nitrogen in the substance. Since the $C: N$ ratio is the key factor that decides the decomposition of the organic material which can have a significant effect on the rate of decomposition, crop nutrient cycling (predominantly nitrogen) and soil nutrient availability. In the raw coir pith $C$ : $\mathrm{N}$ ratio of more than 40:1 might have caused nutrition disorder thus becoming yellowing of young plants. This is also invigorated by coir pith dust chemical composition. In forestry products (bark, sawdust and woodchips) as well as compost container substrates can invite problems of phytotoxicity, which is largely depending on the chemical composition of the substrate, which in turn can cause salinity, nutritional disorders and enzymatic or hormonal metabolic alterations (Ortega et al., 1996). High potassium and manganese content (Maher and Thomson, 1991) and the presence of phenolic compounds are terpenes, organic acids and fatty acids (Morel and Guillemain, 2004) can also be the cause of such problems (Gruda et al., 2009).

Whereas in coir pith composted using PITH PLUS (Pleurotus sajor caju), the C: $\mathrm{N}$ ratio 19:1 were balanced and nutrients are available to the plants (Table 1) as it was inoculated with bio-formulations involving the addition of supplemental substances to substrates to eliminate the "weaknesses" of natural wooden materials like coir pith, hydrolysis of woodchips under pressure in the presence of

Table 1: The C: $\mathrm{N}$ ratio of coir pith and compost coir pith.

\begin{tabular}{lcc}
\hline Parameters & Coir pith & Compost coir pith \\
\hline TOC $(\%)$ & 59.39 & 30.80 \\
Total $N(100 \mathrm{~g})$ & 0.84 & 0.94 \\
C:N ratio & $40: 1$ & $19: 1$ \\
\hline
\end{tabular}


acids (Lemaire et al., 1989). Using this method, the lignincellulose ratio was changed from 1: 2-3 to 1: 1-2. The supply of nitrogen and other mineral additives before manufacturing fiber substrates under high pressure and heat in the presence of water vapor, to improve substrate properties, is called "impregnation (Penningsfeld, 1992).

The germination and seedling growth of black gram and green gram were inhibited by coir pith and composted coir pith aqueous extracts compared to the distilled water. Raw coir pith aqueous extracts had a more inhibitory effect on the black gram and green gram when compared to the composted coir pith aqueous extracts. The inhibition is due to phytotoxins present in the extracts, instead of osmotic inhibition because the use of $10 \%$ extract ensures low osmolality (Orwa et al., 2009). The readily visible effects include inhibited or retarded germination rate (Williamson et al., 1992), seeds darkening and swelling, reduced root or radicle (Parafiniuk and Czerwińska, 2019) and shoot or coleoptile extension (Turk and Tawaha, 2003; Bhatt and Todaria, 1990), swelling or necrosis of root tips, curling of the root axis, discoloration, lack of root hairs, reduced dry weight accumulation and lowered reproductive capacity (Ayeni et al., 1997).

The coir pith aqueous extracts had the highest suppression of germination (46.00 and $51.00 \%)$, root length $(5.06$ and $7.55 \mathrm{~cm})$, shoot length $(11.07$ and $13.60 \mathrm{~cm})$ Fresh weight $(0.169$ and $0.332 \mathrm{mg})$ and dry weight $(0.010$ and $0.018 \mathrm{mg}$ ) of black gram and green gram respectively. It was compared to aqueous extracts composted coir pith and distilled water (Table 2).
The RI indicated the highest negative (-) values coir pith aqueous extracts of germination $(-0.425$ and -0.271$)$, root length $(-0.476$ and -0.321$)$ of black gram and green gram respectively. Whereas, the negative RI of black gram $(-0.677)$ and green gram $(-0.125)$ of shoot length. The black gram $(-0.817$ and -0.384$)$ of fresh weight and dry weight were registered respectively. With regards to the highest RI of positive $(+)$ values registered in the composted coir pith compared to the raw coir pith RI (Table 3 , Fig 1 and 2).

The chemical class distributions of the coir pith extracts are summarized in Table 4 and the GCMS/MS Chromatogram in Fig 3. The compounds were separated into eight classes: Acid, Alcohol, Alkane, Amide, Azo compound, Ester, Ketone and Pyrimidine. Among the 29 chemical compounds, the alcohol class of Tocopherol showed severe seedling growth inhibition phenotype, suggesting that PC-8 functions as a lipid antioxidant in early plant development (Mène-Saffrané et al., 2010) and Fucoxanthin derived of strigolactone, has recently identified phytohormone involved in the inhibition of shoot branching of young plants, is also derived from carotenoids (Umehara et al., 2008; Gomez-Roldan et al., 2008; Seto et al., 2012). The alkane class of Tetramethylheptadeca and Dichloroacetamide inhibited leaf growth as induced by auxin was found to be independent of ethylene in common bean (Phaseolus vulgaris) plants (Keller et al., 2004). The inhibition of ethylene by applying $1 \mathrm{mM}$ ethylene synthesis inhibitor aminooxy acetic acid (AOA) with $1 \mathrm{mM}$ IAA did not affect auxin-induced inhibition of leaf growth. The Azo compound of Tetrazole has been found useful as an inhibitor of top growth for vegetables, fruit trees, cereals and canes.

Table 2: Inhibition effect of black gram and green gram germination and seedling growth.

\begin{tabular}{lccccc}
\hline & Germination \% & Root length $(\mathrm{cm})$ & Shoot length $(\mathrm{cm})$ & Fresh weight $(\mathrm{mg})$ & Dry weight $(\mathrm{mg})$ \\
\hline Coir pith & & & & & \\
Black gram & $46.00 \pm 0.173$ & $5.06 \pm 1.703$ & $11.07 \pm 3.707$ & $0.169 \pm 0.058$ & $0.010 \pm 0.003$ \\
Green gram & $51.00 \pm 0.690$ & $7.55 \pm 1.090$ & $13.60 \pm 2.716$ & $0.332 \pm 0.042$ & $0.018 \pm 0.004$ \\
Composted coir pith & & & & \\
Black gram & $51.42 \pm 0.884$ & $5.47 \pm 1.519$ & $11.59 \pm 3.938$ & $0.247 \pm 0.061$ & $0.015 \pm 0.005$ \\
Green gram & $60.00 \pm 0.730$ & $7.91 \pm 0.936$ & $17.99 \pm 2.294$ & $0.392 \pm 0.053$ & $0.016 \pm 0.005$ \\
Distilled water & & & & & \\
Black gram & $80.00 \pm 0.149$ & $7.470 \pm 1.306$ & $18.56 \pm 2.843$ & $0.307 \pm 0.058$ & $0.014 \pm 0.003$ \\
Green gram & $70.00 \pm 0.843$ & $9.970 \pm 1.455$ & $15.30 \pm 3.133$ & $0.263 \pm 0.064$ & $0.014 \pm 0.004$ \\
\hline
\end{tabular}

Data are the mean values of three replicates with \pm standard error.

Table 3: Response index values for inhibition effect of black gram and green gram germination and seedling growth

\begin{tabular}{lccccc}
\hline Coir pith RI & $\begin{array}{c}\text { Germination } \\
\%\end{array}$ & $\begin{array}{c}\text { Root length } \\
(\mathrm{cm})\end{array}$ & $\begin{array}{c}\text { Shoot length } \\
(\mathrm{cm})\end{array}$ & $\begin{array}{c}\text { Fresh weight } \\
(\mathrm{mg})\end{array}$ & $\begin{array}{c}\text { Dry weight } \\
(\mathrm{mg})\end{array}$ \\
\hline Response index of coir pith & & & & & \\
Black gram & -0.425 & -0.476 & -0.677 & -0.817 & -0.384 \\
Green gram & -0.271 & -0.321 & -0.125 & +0.207 & +0.203 \\
Response Index of composted coir pith & & & & -0.196 & +0.117 \\
Black gram & -0.357 & -0.268 & -0.376 & +0.328 & +0.116 \\
Green gram & -0.143 & -0.207 & +0.150 & 0.00 & 0.00 \\
Distilled water & 0.00 & 0.00 & 0.00 & & \\
\hline
\end{tabular}


Application of 5-amino tetrazole to the soil at planting time has caused temporary albinism in some plants and reduction of tetrazolium salts to red-colored formazans has been used to detect the activity of reducing enzymes in seeds. The Ester class of Hydroxyethyl palmitate is the derivation of $\mathrm{N}$ Acylethanolamines (NAEs). The new phenoxyacyl-

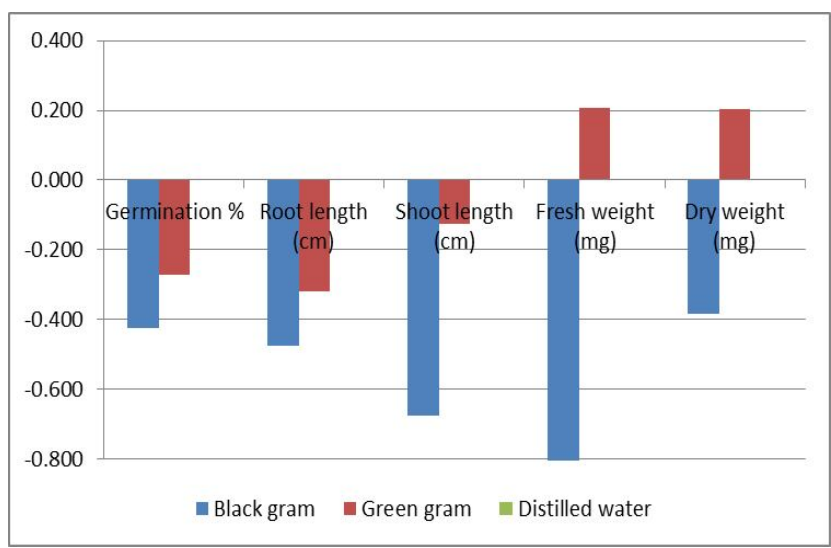

Fig 1: Response index values of coir pith on black gram and green gram. ethanolamides may be able to enhance endogenous FAAH activity in wild-type seedlings, to confer some tolerance to the growth inhibition by NAE (Lionel Faure et al., 2014). The Ketone class of Neocurdione is a development of amine oxidase in the apical part was inhibited by administration of neocuproine and this effect was markedly reversed by the addition of copper disodium ethylene diamine tetraacetate (EDTA-Na $-\mathrm{Cu}$ ) (Yonezo Suzuki and Hiroshi Yanagisawa, 1976) and the Pyrimidine class of Uridine is inhibition of potato tuber of de novo pyrimidine synthesis leads to a compensatory stimulation of the pyrimidine salvage pathway (Geigenberger et al., 2005). The presence of the above bioactive compounds in the coir pith may act as an inhibitory agent for young plants like black gram and green gram.

The chemical class distributions of the composted coir pith constituents extracts are summarized in Table 5 and the GCMS/MS Chromatogram of Fig 4. The compounds were separated into seven classes: Acid, Alcohol, Aldehyde, Alkane, Amide, Ester and Guanidine. Among the seven class compounds that mostly come under the characteristic feature of fatty acids is the carboxyl function. The composted coir pith while decomposition polyphenol content contains and phenolic compounds is less by degraded. The

Table 4: Chemical compounds in coir pith by GCMS/MS.

\begin{tabular}{|c|c|c|c|}
\hline Retention time & Area/Height (\%) & Compound name & Compound class \\
\hline 20.643 & 3.82 & n-Hexadecanoic acid & Acid \\
\hline 23.984 & 4.52 & 9-Octadecenoic acid, (E)- & Acid \\
\hline 24.419 & 5.45 & Octadecanoic acid & Acid \\
\hline 27.935 & 4.51 & Succinic acid, 1,1,1-trifluoropro & Acid \\
\hline 28.385 & 3.19 & 2-Bromopropionic acid, 6-ethyl & Acid \\
\hline 28.565 & 2.56 & Doconexent, TMS derivative & Acid \\
\hline 29.586 & 5.27 & .alpha.-Hydroxystearic acid & Acid \\
\hline 30.584 & 2.29 & Fumaric acid, dodecyl 2-hexyl e & Acid \\
\hline 27.472 & 4.08 & .alpha.-Tocopherol-.beta.-D-ma & Alcohol \\
\hline 27.655 & 2.49 & Cholest-7-en-3-ol, 4,4-dimethyl & Alcohol \\
\hline 29.280 & 1.46 & Fucoxanthin & Alcohol \\
\hline 29.759 & 2.62 & Isofucosterol, O-TMS & Alcohol \\
\hline 22.992 & 3.88 & Eicosane & Alkane \\
\hline 26.588 & 5.09 & Octacosane, 1-iodo- & Alkane \\
\hline 27.591 & 7.42 & $4,8,12,16$-Tetramethylheptadeca & Alkane \\
\hline 28.278 & 5.57 & Eicosane & Alkane \\
\hline 29.952 & 6.30 & Hexadecane, 2,6,10,14-tetramet & Alkane \\
\hline 27.804 & 4.06 & Dichloroacetamide, N-nonyl- & Amide \\
\hline 28.620 & 2.85 & Butyramide, 2-bromo-N-octyl- & Amide \\
\hline 27.780 & 2.28 & Tetrazole, 5-[2-(1-perhydroazep & Azo compound \\
\hline 29.852 & 2.05 & Methyl 2,3-dihydroxybenzoate, & Ester \\
\hline 30.046 & 4.01 & Valtrate & Ester \\
\hline 26.864 & 2.87 & 2-Hydroxyethyl palmitate, TMS & Ester \\
\hline 26.029 & 4.00 & Neocurdione & Ketone \\
\hline 27.185 & 1.77 & Norbolethone & Ketone \\
\hline 29.255 & 2.22 & 2-Methyl-6-(5-methyl-2-thiazolidone & Ketone \\
\hline 29.479 & 2.06 & Geldanamycin, 18,21-didehydro & Ketone \\
\hline 30.937 & 3.35 & Dihydroartemisinin, 5-de hydro & Ketone \\
\hline 30.185 & 2.64 & Uridine, 2',3'-O-(1-methylethyli & Pyrimidine \\
\hline
\end{tabular}


Allelopathic Chemical Screening of Aqueous Extracts of Coir Pith on Seedling Growth of Black Gram (Vigna mungo L.) and...

Table 5: Chemical compounds in composted coir pith by GCMS/MS.

\begin{tabular}{|c|c|c|c|}
\hline Retention time & Area / Height (\%) & Compound name & Compound class \\
\hline 12.256 & 4.13 & Dodecanoic acid & Acid \\
\hline 16.532 & 3.06 & Tetradecanoic acid & Acid \\
\hline 17.848 & 3.29 & Pentadecanoic acid & Acid \\
\hline 18.494 & 2.74 & 1,2-Benzenedicarboxylic acid, b & Acid \\
\hline 20.211 & 3.25 & Oleic Acid & Acid \\
\hline 20.630 & 3.56 & n-Hexadecanoic acid & Acid \\
\hline 21.832 & 2.82 & Eicosanoic acid & Acid \\
\hline 23.960 & 3.53 & 9-Octadecenoic acid (Z)-, 2,3-di & Acid \\
\hline 24.392 & 3.70 & Octadecanoic acid & Acid \\
\hline 24.733 & 2.27 & Acetic acid, chloro-, octadecyl e & Acid \\
\hline 27.900 & 3.45 & Hydroxyvalerenic acid & Acid \\
\hline 30.615 & 6.04 & Retinoyl-.beta.-glucuronide $6{ }^{\prime}, 3^{\prime}$ & Acid \\
\hline 22.825 & 4.17 & Behenic alcohol & Alcohol \\
\hline 22.966 & 3.13 & 7-Hexadecyn-1-ol & Alcohol \\
\hline 30.000 & 1.59 & Perillaldehyde-O-methyloxime & Aldehyde \\
\hline 17.991 & 3.78 & Docosanoic acid, 1,2,3-propane & Alkane \\
\hline 20.965 & 2.85 & 9-Hexacosene & Alkane \\
\hline 24.820 & 6.60 & Decane, 5-ethyl-5-methyl- & Alkane \\
\hline 28.267 & 2.35 & Hexacosane, 1-iodo- & Alkane \\
\hline 31.139 & 3.43 & 5-(7-Isopropyl-10-methyl-1-oxo & Alkane \\
\hline 24.030 & 4.01 & Cyclohexanol, 1R-4cis-acetamid & Amide \\
\hline 29.946 & 3.90 & Nonivamide & Amide \\
\hline 19.684 & 2.50 & Hexadecanoic acid, methyl ester & Ester \\
\hline 20.425 & 2.93 & Dibutyl phthalate & Ester \\
\hline 25.037 & 2.56 & Eicosyl acetate & Ester \\
\hline 30.779 & 3.40 & Bis(2-ethylhexyl) phthalate & Ester \\
\hline 26.790 & 3.06 & n-Octyl guanidine & Guanidine \\
\hline
\end{tabular}

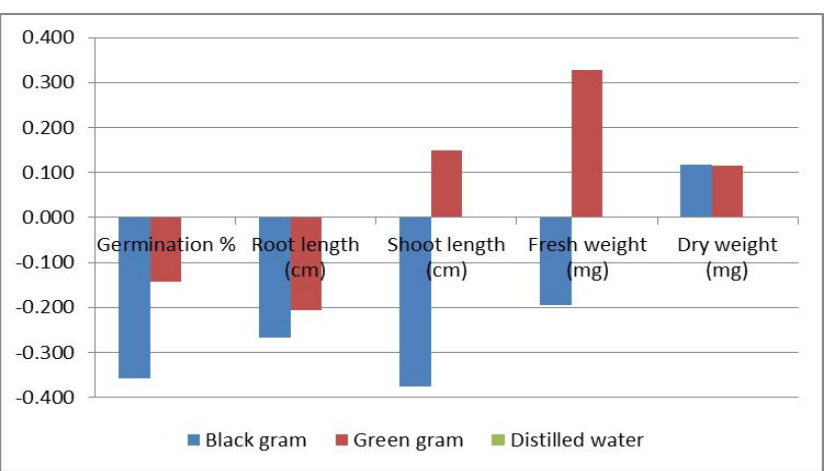

Fig 2: Response index values of composted coir pith on black gram and green

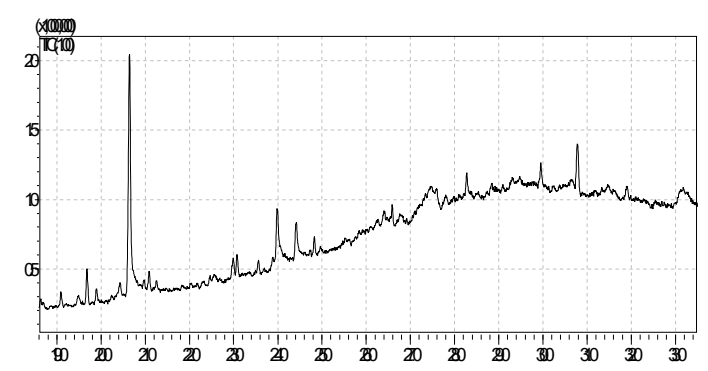

Fig 3: GCMS/MS Chromatogram of coir pith.

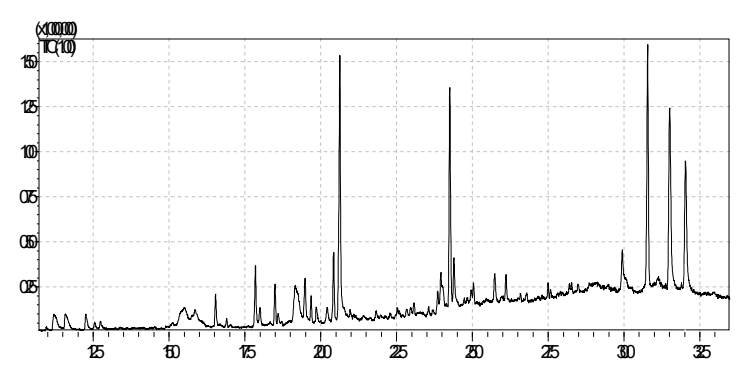

Fig 4: GCMS/MS Chromatogram of composted coir pith.

microorganisms can utilize and degrade polyphenols (Chan, 1986) and as many polyphenols are water-soluble nature coir pith. The composted coir pith has a low $\mathrm{C}: \mathrm{N}$ ratio, which provides nutrients for crops (Bollen and Lu, 1957).

\section{CONCLUSION}

Despite numerous advantages and accessibility in huge amounts, the coir substance is not completely used for gainful purposes due to the high $\mathrm{C}$ : $\mathrm{N}$ proportion (112: 1) and the presence of a high amount of lignin. The use of raw coir pith with a wide $\mathrm{C}$ : $\mathrm{N}$ proportion can bring about immobilization of plant supplements. Also, polyphenols and 
phenolic acids can be phytotoxic and repress plant development and hence it can be used for moisture conservation and other related works while composted coir pith can be used for various agricultural and horticultural works including nurseries. Besides, composted coir pith is also a good source of organic matter for agricultural use for soil health building.

\section{ACKNOWLEDGEMENT}

The authors wish to thank the Core Projects for research activities at College and Research stations of TNAU - Phase III (Post Doctoral Fellowships), funded by Agriculture Department, Govt. of Tamil Nadu, 2018 - 2021, Tamil Nadu Agricultural University, Coimbatore, India. Also, wish to thank the Department of Entomology, AC and RI, Madurai, TNAU for the laboratory facilities.

\section{REFERENCES}

Anbarasu, M., Swaminathan, C. (2021). Inhibitory effect of aqueous extracts of tree-legumes on germination and seedling growth of food legume, green gram (Vigna radiata L.). Legume Research. DOI: 10.18805/LR-4545.

Ayeni, A.O., Lordbanjou, D.T., Majek B.A. (1997). Tithonia diversifolia (Mexican sunflower) in south-western Nigeria: occurrence and growth habit. Weed Research. 37: 443- 449.

Bhatt, B.P., Todaria, N.P. (1990). Studies on the allelopathic effects of some agroforestry tree crops of Garhwal Himalaya. Agroforestry Systems. 12: 251-255.

Bollen, W.B., Lu, K.C. (1957). Effect of Douglas-fir sawdust mulches and incorporations on soil microbial activities and plant growth. Soil Science Society of America Proceedings. 21(1): 35-41.

Bremmer, J.M. and Mulvaney. C.S. (1982). Nitrogen-total. In: [Page, A.L., Miller, R.H., Keeney, D.R. (Eds.)], Methods of Soil Analysis, Part 2. Chemical and Microbiological Properties, second ed., Agronomy series No. 9 ASA, SSSA, Madison.

Chan, Y.K. (1986). Utilization of simple phenolics for di nitrogen fixation by soil diazotmphlc bacteria. Plant Soil. 90: 141-150.

Geigenberger, P., Regierer, B., Nunes-Nesi, A., Leisse, E., UrbanczykWochniak, F., Springer, J.T., Van Dongen, J., Kossmann, J., Fernie, A.R. (2005). Inhibition of de novo pyrimidine synthesis in growing potato tubers leads to a compensatory stimulation of the pyrimidine salvage pathway and a subsequent increase in biosynthetic performance. Plant Cell. 17: 2077-2088.

Gomez, K.A., Gomez, A.A. (1984). Statistical Procedures for Agricultural Research, $2^{\text {nd }}$ Edn.; John Wiley Sons, New York.

Gomez-Roldan, V., Fermas, S., Brewer, P.B., Puech-Pagès, V., Dun, E.A., Pillot, J.P., Letisse, F., Matusova, R., Danoun, S., Portais, J.C., Bouwmeester, H., Bécard, G., Beveridge, C.A., Rameau, C., Rochange, S.F. (2008). Strigolactone inhibition of shoot branching. Nature. 455: 189-194.

Gruda, N., Rau, B., Wright, R.D. (2009). Laboratory bioassay and greenhouse evaluation of a pine tree substrate used as a container substrate. European Journal of Horticultural Science. 74(1): 73-78.
Keller, C.P., Stahlberg, R., Barkawi, L.S. and Cohen, J.D. (2004). Long-term inhibition by auxin of leaf blade expansion in bean and Arabidopsis. Plant Physiology. 134(3): 17-26.

Lemaire, F., Dartigues, A., Riviere, L.M. (1989). Physical and chemical characteristics of a lignocellulosic material. Acta Horticulturae. 238: 9-22.

Lionel Faure., Subbiah Nagarajan., Hyeondo Hwang., Christa L. Montgomery., Bibi Rafeiza Khan., George John., Peter Koulen., Elison B Blancaflor., Kent D Chapman. (2014). Synthesis of Phenoxyacyl-Ethanolamides and Their Effects on Fatty Acid Amide Hydrolase Activity. Journal of Biological Chemistry. 289(13): 9340-9351.

Maher, M.J., Thomson, D. (1991). Growth and Mn content of tomato (Lycopersicon esculentum) seedlings grown in Sitka spruce [Picea sitchensis (Bong.) Carr.] bark substrate. Science of Horticulture. 48: 223-231.

Mène-Saffrané, L., Jones, A.D., Della Penna, D. (2010). Plastochromanol -8 and tocopherols are essential lipid-soluble antioxidants during seed desiccation and quiescence in Arabidopsis. Proc Natural Academic Science. USA 107: 17815-17820.

Morel, P., Guillemain, G. (2004). Assessment of the possible phytotoxicity of a substrate using an easy and representative biotest. Acta Horticulturae. 64: 417-423.

Ortega, M.C., Moreno, M.T., Ordovas, J., Aguado, M.D. (1996). Behavior of different horticultural species in phytotoxicity bioassays of bark substrates. Science Horticultre. 66 : 125-132.

Orwa, C., Mutua, A., Kindt, R., Jamnadass, R., Anthony, S. (2009). Agroforestree database: $A$ tree reference and selection guide version 4.0. http://www.worldagroforestry.org.

Parafiniuk, S., Czerwiñska, E. (2019). In vitro Allelopathic Effects of Plant Extracts on Germination of Vicia fabia (partim) Seeds. Legume Research: 42(6): 789-794.

Penningsfeld, F. (1992). Toresa a new substrate for soilless culture. Eighth Intl Congress on Soilless Culture. Hunter's Rest South Africa. ISOSC Proceedings. p. 335-345.

Richardson, D.R., Williamson, G.B. (1988). Allopathic effects of shrubs of the sand pine scrub on pines and grasses of the sandhills. Forest Science. 34(3): 592- 605.

Seto,Y., Kameoka, H., Yamaguchi, S., Kyozuka, J. (2012). Recent advances in strigolactone research: Chemical and biological aspectes. Plant and Cell Physiology. 53: 1843-1853.

Turk, M.A., Tawaha, A.M. (2003). Allelopathic effect of black mustard (Brassica nigra L.) on germination and growth of wild oat (Avena fatua L.). Crop Protection. 22: 667-673.

Umehara, M., Hanada, A., Yoshida, S., Akiyama, K., Arite, T., TakedaKamiya, N., Magome, H., Kamiya, Y., Shirasu, K., Yoneyama, $\mathrm{K}$. and et al. (2008). Inhibition of shoot branching by new terpenoid plant hormones. Nature. 455: 195-200.

Williamson, G.B., Richardson, D.R., Fischer, N.H. (1992). Allelopathic mechanism in fire-prone communities in Allelopathy. Chapman and Hall, London, UK pp. 59-75.

Yonezo Suzuki., Hiroshi Yanagisawa. (1976). Effect of neocuproine and cuprizone on the development of amine oxidase and growth in pea seedlings. Plant and Cell Physiology. 17(6): 1359-1362. 